\title{
Mormo em eqüídeos nos Estados de Pernambuco e Alagoas ${ }^{1}$
}

INDEX TERMS: Glanders, equids, Northeast Brazil.

RESUM0.- Com base em aspectos clínico-patológicos, epidemiológicos e sorológicos, bem como pelo isolamento de Burkholderia mallei, diagnosticaram-se focos de mormo em eqüídeos na Zona da Mata dos Estados de Pernambuco e Alagoas. Clinicamente observaram-se hipertermia, respiração ruidosa, inapetência, emagrecimento progressivo até caquexia, congestão nasal e descarga mucopurulenta, erosões, úlceras e cicatrizes na mucosa nasal. Os linfonodos mandibulares e cervicais superficiais apresentavam-se aumentados de volume, com abscessos e fístulas exsudando material purulento. Na pele, ao longo dos vasos linfáticos, havia formação de nódulos firmes e abscessos que, nos casos crônicos, fistulavam e ulceravam deixando cicatrizes estrelares. A histopatologia dos nódulos de diversos sítios, tanto dos

\footnotetext{
${ }^{1}$ Aceito para publicação em 27 de junho de 2000.

${ }^{2}$ Departamento de Medicina Veterinária da Universidade Federal Rural de Pernambuco (UFRPE), Rua Dom Manoel de Medeiros s/no, Dois Irmãos, Recife, PE 52171-900.

${ }^{3}$ Departamento de Epidemiologia e Saúde Pública da Universidade Federal Rural do Rio de Janeiro. E-mail: marilene@ ufrrj.br

${ }^{4}$ Mestrando do Curso de Pós-Graduação em Ciência Veterinária, UFRPE.

5 Médico Veterinário autônomo.

${ }^{6}$ PADOC, Jockei Club de SP, através do Ministério da Agricultura.
}

eqüídeos como dos cobaios utilizados na prova de Straus, revelou lesões granulomatosas e piogranulomas. Os dados deste estudo evidenciam a emergência da doença nesta área e permitem recomendar inquéritos soro-epidemiológicos nos Estados de ocorrência dos surtos e nos Estados limítrofes.

TERMOS DE INDEXAÇÃO: Mormo, eqüídeos, Nordeste do Brasil.

\section{INTRODUÇÃO}

O mormo é uma das mais antigas doenças dos eqüídeos, já mencionada por Aristóteles e Hipócrates nos séculos II e IV a.C. É causada por um bacilo inicialmente denominado Bacillus mallei e como Actinobacillus mallei (Langenegger et al. 1960). Com base em características bioquímicas e nutricionais essa bactéria foi classificada posteriormente no gênero Pseudomonas (Redfearn et al. 1966); em 1980 o agente foi incluído sob a denominação Pseudomonas mallei na "Approved List of Bacterial Names". Baseados na biologia molecular, na composição de lipídeos e ácidos graxos e em características fenotípicas Yabuuchi et al. (1992) colocaram esta bactéria em um novo gênero, denominado Burkholderia.

Responsável por alta taxa de mortalidade em eqüídeos, a doença ocorre em diferentes partes do mundo, tendo sido descrita no Iraque (Al-Ani et al. 1987), no Egito e em certas partes da África (Henning 1956), na Itália (Battelli et al. 1973), na Índia (Gangulee et al.1966; Verma et al. 1994), na China 
(Zhang \& Lú 1983) e na Rússia (Shumilov 1974). A doença foi erradicada nos Estados Unidos, na Inglaterra e na Austrália (Henning 1956).

De acordo com os dados revisados por Langenegger et al. (1960), no Brasil a doença foi descrita pela primeira vez em 1811 , introduzida provavelmente por animais infectados importados da Europa (Pimentel 1938), desencadeando-se verdadeiras epizootias em vários pontos do território nacional, vitimando muares, cavalos e humanos que adoeceram com sintomatologia de catarro e cancro nasal.

Após vários relatos da ocorrência da enfermidade em eqüídeos e humanos, com caracterização dos achados epidemiológicos, clínicos, microbiológicos e anatomo e histopatológicos, a doença parecia ter sido erradicada no Brasil; a última referência a um foco de mormo no município de Campos, Estado do Rio de Janeiro, foi feita por Langenegger et al. (1960).

0 presente estudo teve como objetivo registrar a ocorrência de focos de mormo em eqüídeos nos Estados de Pernambuco e Alagoas, bem como caracterizar seus aspectos epidemiológicos, sorológicos e clínico-patológicos.

\section{MATERIAL E MÉTODOS}

A doença foi estudada em três propriedades rurais nas quais foram realizadas visitas, levantamentos dos históricos e exames clínicos dos animais doentes; os eqüídeos em estado mais grave foram necropsiados. Duas fazendas estão localizadas na Zona da Mata do Estado de Pernambuco, nos municípios de Barra de Serinhaém e Cortês, e uma na Zona da Mata do Estado de Alagoas, no município de São José das Lages.

\section{Isolamento bacteriano}

0 pus dos nódulos cutâneos dos eqüídeos foi assepticamente colhido por meio de punção aspirativa e semeado em agar sangue ovino a 5\% agar Levine, agar Mac Conkey, agar SS, batata glicerinada e agar batata glicerinada. Foram feitos esfregaços do conteúdo purulento dos nódulos e corados pelo método de Gram.

Para identificação bacteriana foram analisados os aspectos de crescimento, características morfo-tintoriais à técnica de Gram, provas bioquímicas como oxidase, catalase, indol, redução do nitrato, Voges Proskauer, vermelho de metila, produção de $\mathrm{H}_{2} \mathrm{~S}$, produção de $\mathrm{NH}_{3}$, liquefação da gelatina, motilidade, crescimento a $42^{\circ} \mathrm{C}$ e produção de pigmento, lisina, ornitina, arginina e carboidratos (glicose, maltose e lactose).

As bactérias isoladas a partir dos testículos, linfonodos, baço e fígado dos cobaios inoculados também foram submetidas às mesmas provas de identificação.

\section{Inoculação em cobaios}

0 exsudato purulento, colhido dos nódulos cutâneos e a suspensão bacteriana obtida após o cultivo em meios sólidos, foram inoculados em quatro cobaios machos por via subcutânea e intraperitoneal, respectivamente. Os cobaios, observados por duas semanas, foram posteriormente sacrificados para realização de necropsias e colheita de material das lesões para re-isolamento bacteriano nos meios citados anteriormente.

\section{Sorologia}

Para o diagnóstico sorológico utilizou-se o teste de fixação do complemento, de acordo com técnica descrita por Verma (1990), considerando-se títulos de 1:16 como significativos e 1:8 ou menores como insignificantes ${ }^{6}$.

\section{Exames clínicos, anatomo e histopatológicos}

Cerca de 15 eqüídeos foram examinados durante as visitas às três propriedades envolvidas neste estudo. Destes, quatro eqüídeos foram sacrificados in extremis. Dois cobaios foram sacrificados no final da segunda semana de inoculação e o terceiro cobaio morreu no 8o dia após a inoculação. 0 material destinado aos exames histopatológicos foi fixado em fomalina a $10 \%$ Os fragmentos coletados foram submetidos às técnicas usuais de processamento histológico.

\section{RESULTADOS}

\section{Histórico}

Todas as propriedades visitadas utilizavam os muares e eqüinos exclusivamente como animais de tração e de sela, para 0 trabalho de produção e beneficiamento da cana-deaçúcar. Eram alimentados à base de pastagem nativa, broto de cana-de-açúcar e melaço. A doença vinha acometendo os eqüídeos há aproximadamente 5 anos. Observou-se que a doença ocorre, na maioria dos casos deste estudo, em animais idosos e debilitados pelas más condições de manejo e nutrição. Nas duas propriedades visitadas em Pernambuco houve uma perda aproximada de 300 eqüídeos e, na de Alagoas, em torno de 100 animais. Clinicamente, a doença afeta os sistemas respiratório e linfático, ocasionando morbidade e mortalidade elevadas e é conhecida popularmente como "doença do catarro" e "catarro-bravo". Tentativas de diagnóstico, tratamento e controle da enfermidade tiveram resultados insatisfatórios ao longo desses 5 anos. 0 leucograma de alguns desses animais revelou um quadro de leucocitose com neutrofilia e fibrinogênio elevado. As tentativas de tratamento, muito embora sempre dirigidas para alcançar outras bactérias inicialmente isoladas, resultaram em fracasso e se basearam na utilização de oxitetraciclina, penicilina, sulfas, cloranfenicol e cefalosporina. Aqueles animais, em que houve tentativa de tratamento, apresentaram uma redução do nível de fibrinogênio, mas não atingiam os valores considerados normais para a espécie.

\section{Achados microbiológicos}

A partir do pus aspirado dos nódulos subcutâneos amolecidos, mas não ulcerados ou fistulados, e semeado em agar sangue, observou-se o crescimento de numerosas e pequenas colônias não-hemolíticas, de coloração ligeiramente acinzentada, após 48 horas de incubação. 0 crescimento em batata glicerinada foi caracterizado pela presença de pigmento amarelado, lembrando mel, após 48 horas de incubação, tornando-se achocolatado 24 horas depois. Não foi observado crescimento em agar Levine. A bactéria re-isolada dos órgãos dos cobaios inoculados por via subcutânea e intraperitoneal apresentou as mesmas características de crescimento. Nos esfregaços realizados com o pus e com as colônias obtidas em agar sangue e em agar batata glicerinado foram observados microrganismos irregulares, Gram negativos, isolados ou em filamentos. 


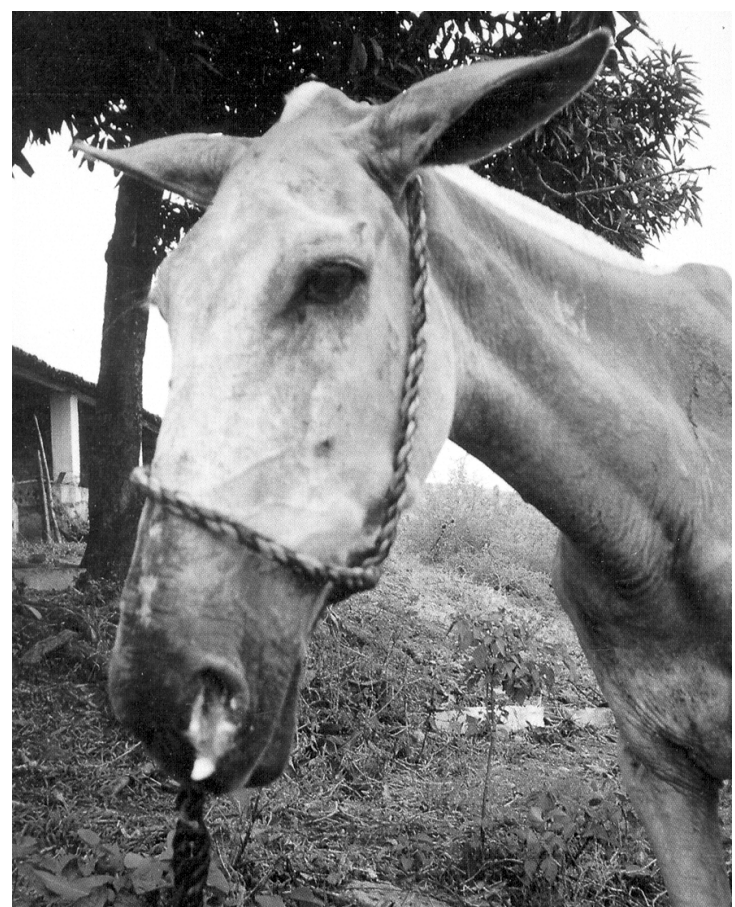

Fig. 1. Mormo em eqüídeo. Descarga nasal muco-purulenta.

\section{Achados sorológicos}

Das 20 amostras de soro dos eqüídeos analisadas, sete se mostraram positivas, representando um percentual de $35 \%$ na amostragem estudada (Quadro 1).

\section{Achados clínico-patológicos}

As alterações clínicas e os achados de necropsia mais importantes estavam relacionados com os sistemas respiratório e linfático.

Os eqüídeos examinados em todas as propriedades demonstraram hipertermia $\left(39,8^{\circ} \mathrm{C}\right.$ até $\left.40,5^{\circ} \mathrm{C}\right)$, descarga nasal muco-purulenta (Fig. 1), algumas vezes acompanhada de sangue em ambas as narinas. Havia congestão, erosões e presença de úlceras principalmente no septo nasal. Nos casos crônicos, as úlceras resultavam em cicatrizes irregulares ou estelares e deprimidas na mucosa nasal, muitas vezes com destruição do septo nasal. Havia dispnéia, respiração ruidosa, estertores pulmonares, inapetência e, nos casos crônicos da doença, emagrecimento progressivo.

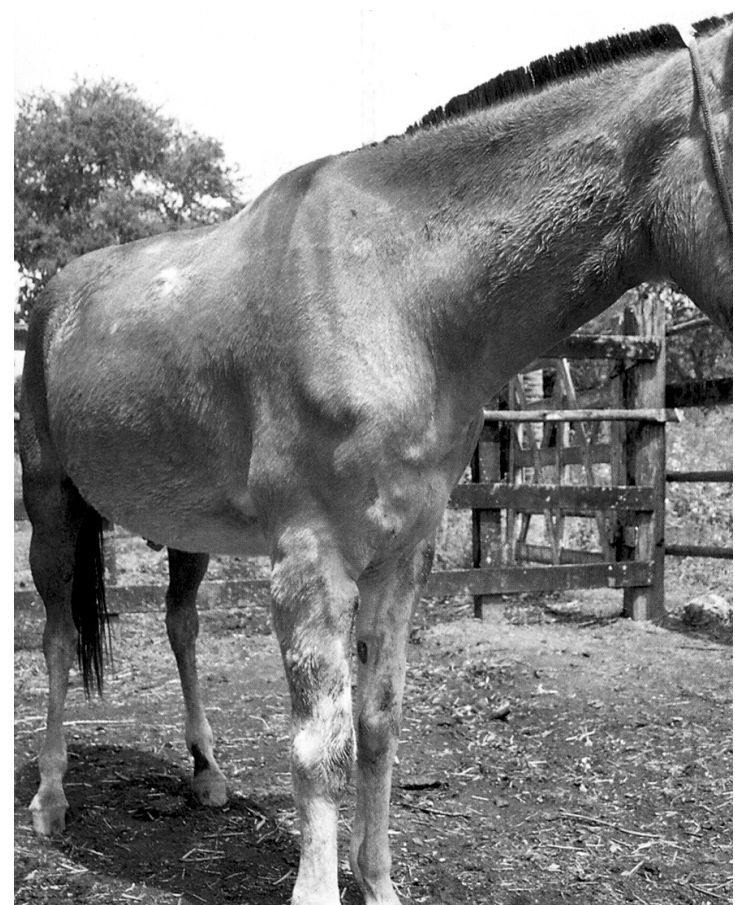

Fig. 2. Granulomas na pele em eqüídeo com mormo.

À necropsia, havia petéquias e equimoses na pleura visceral. Os pulmões apresentavam-se com múltiplos abscessos e piogranulomas, com 2 a $3 \mathrm{~cm}$ de diâmetro; alguns nódulos eram firmes.

No sistema linfático observaram-se nódulos firmes, arredondados e elevados, ao longo do trajeto dos vasos linfáticos formando "rosários"; com a evolução estes se tornavam flácidos, fistulavam e drenavam pus branco-amarelado. Estas lesões eram mais freqüentes na cabeça, pescoço e membros (Fig. 2). $\mathrm{Na}$ pele de alguns animais foram observadas cicatrizes profundas em decorrência da formação de úlceras cutâneas.

Os linfonodos mandibulares, cervicais superficiais, précrurais e os relacionados com o trato respiratório eram os mais afetados, apresentando-se aumentados de volume, por vezes fistulados, eliminando material purulento; nos casos crônicos tinham textura fibrosa e estavam aderidos à pele.

Poucos animais apresentaram edema de membros e poliartrite, na fase inicial da doença.

Quadro 1. Diagnóstico sorológico de mormo em eqüídeos da Zona da Mata dos Estados de Pernambuco e Alagoas (outubro de 1999)

\begin{tabular}{|c|c|c|c|c|c|c|c|c|c|c|}
\hline Estado & Município & Total & Positivas & $\%$ & Negativas & $\%$ & Suspeitas & $\%$ & $A C^{a}$ & $\%$ \\
\hline Alagoas & São José das Lages & 5 & 1 & 20 & 3 & 60 & - & - & 1 & 20 \\
\hline Pernambuco & Cortês & 6 & 3 & 50 & 1 & 17 & - & - & 2 & 33 \\
\hline Pernambuco & Sirinhanhém & 9 & 3 & 33 & 3 & 56 & 1 & 11 & - & - \\
\hline Total & & 20 & 7 & 35 & 9 & 45 & 1 & 5 & 3 & 15 \\
\hline
\end{tabular}




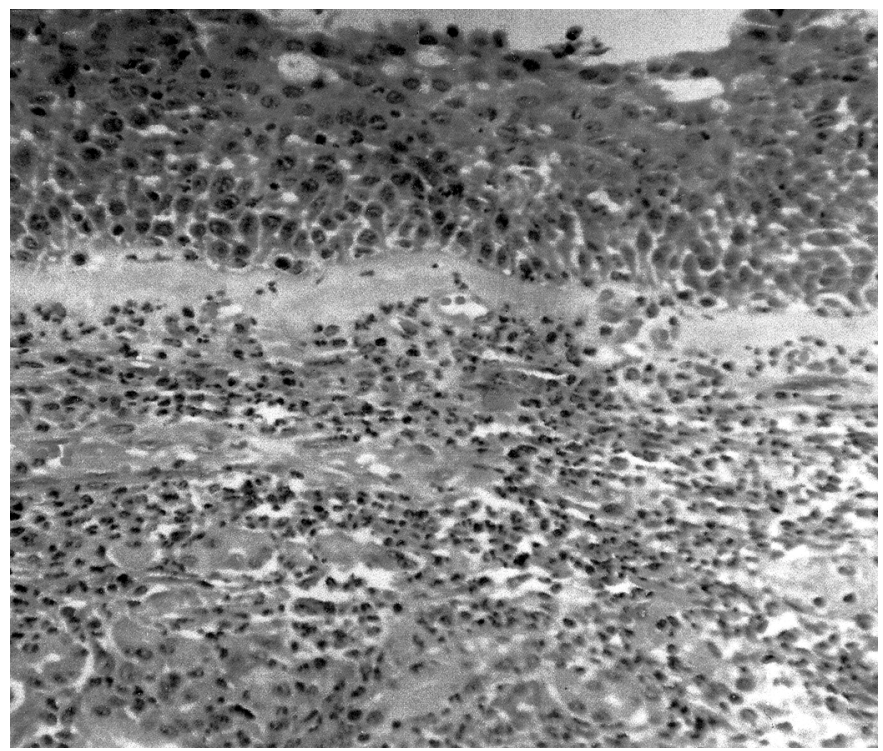

Fig. 3. Inflamação purulenta difusa grave na submucosa nasal com destruição das glândulas e marcada vasculite. Mormo em eqüídeo. HE, obj. 25.

Fig. 4. Prova de Straus positiva. Cobaio apresentando aumento de volume testicular e severa congestão, confirmando o diagnóstico de mormo.

\section{Achados histopatológicos nos eqüídeos}

O exame histológico revelou lesões granulomatosas ou piogranulomatosas; a necrose de caseificação central era circundada por grande quantidade de elementos inflamatórios especialmente macrófagos, células epitelióides, células gigantes, linfócitos, plasmócitos e abundante tecido conjuntivo. Havia áreas de calcificação no tecido necrótico.

Observaram-se grave inflamação purulenta difusa com destruição do epitélio nasal (Fig. 3), glândulas e cartilagem septal, hemorragia, focos de fibrina e marcada vasculite, além de trombose de vasos subepiteliais. No pulmão havia moderada a acentuada congestão e pequenos focos de hemorragia, presença de edema e fibrina interlobular e intra-alveolar e inflamação granulomatosa focal. Nos linfonodos observaram-se necrose, congestão e hemorragia, com numerosos focos de inflamação piogranulomatosa. No fígado verificaram-se necrose e infiltração granulomatosa focais com presença de células gigantes e pericolangite granulomatosa. No baço, foram vistas áreas de necrose fibrinóide, associadas à inflamação piogranulomatosa e a extensas áreas de fibrose. No rim observaram-se infiltração granulomatosa multifocal intersticial com alguns focos de necrose tubular.

\section{Achados clínicos e de necropsia nos cobaios}

O material inoculado em cobaios machos, por via intraperitoneal e subcutânea (prova de Straus), resultou em reação positiva, em três dos quatro cobaios inoculados. Esfregaços e culturas do exsudato purulento foram realizados e permitiram a observação e re-isolamento bacteriano.

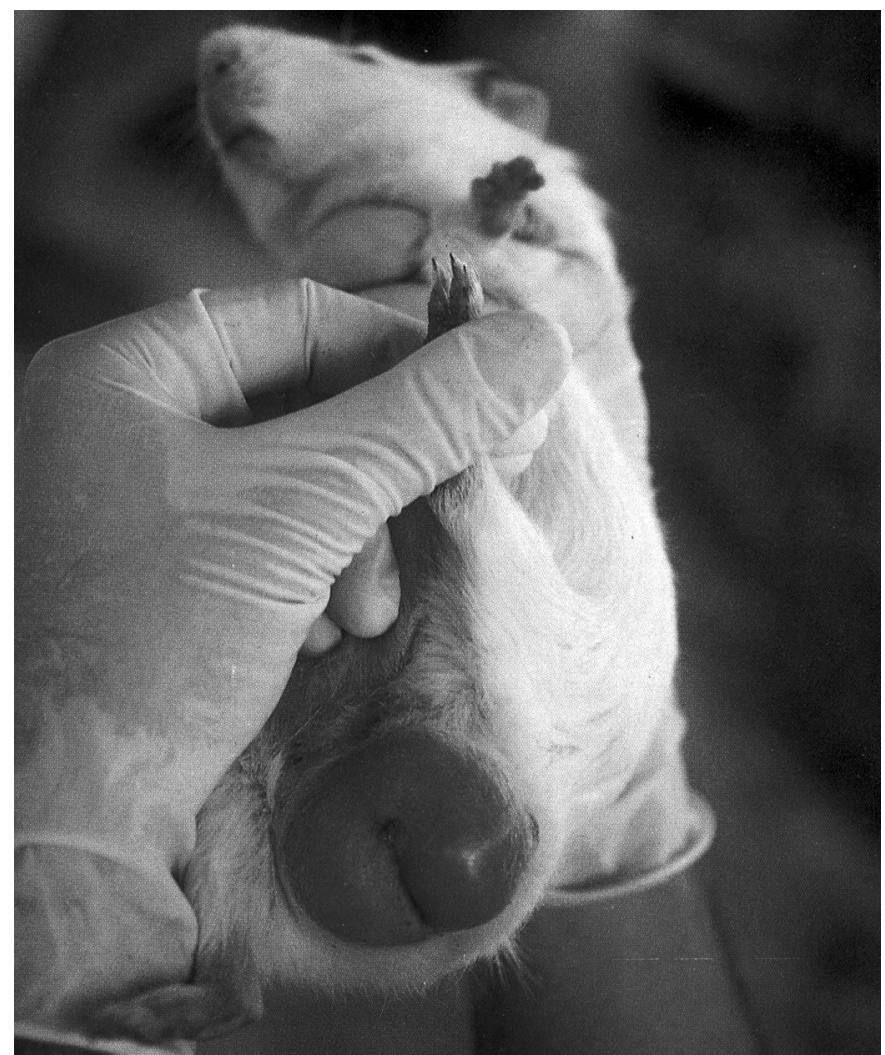

Os cobaios apresentaram febre, apatia, anorexia, aumento de volume testicular (Fig. 4) e de linfonodos regionais. Um dos animais morreu no 80 dia após a inoculação, os outros dois cobaios foram sacrificados no final da segunda semana após a inoculação. Os achados de necropsia consistiram em testículos hiperêmicos, aumentados de volume e aderidos ao saco escrotal, com formação de abscessos e fístulas que drenavam exsudato levemente amarelado. 0 parênquima testicular encontrava-se totalmente destruído e o saco escrotal preenchido por conteúdo purulento. 0 fígado apresentava-se com bordos arredondados, focos de necrose e múltiplos abscessos. Havia pneumonia abscedativa multifocal, esplenomegalia e abscessos esplênicos. Também se observou a formação de múltiplos abscessos em linfonodos, rins, estômago e no tecido subcutâneo, no ponto da inoculação.

\section{Achados histopatológicos nos cobaios}

A histopatologia do material dos três cobaios revelou orquite piogranulomatosa grave, necrose e mineralização tubular. A parede abdominal apresentava severa inflamação piogranulomatosa e calcificação de fibras musculares. No fígado foram observadas moderada degeneração gordurosa difusa de hepatócitos, leve congestão e hepatite piogranulomatosa com presença de colônias bacterianas; no pulmão havia congestão e múltiplos focos de inflamação piogranulomatosa, com presença de numerosos macrófagos e células gigantes. Observou-se ainda, descamação epitelial de brônquios e bronquíolos. 


\section{DISCUSSÃO}

A associação dos dados epidemiológicos com os achados clínico-patológicos, microbiológicos, sorológicos e com as provas biológicas, relatados neste estudo, permite o estabelecimento do diagnóstico de mormo. Os dados epidemiológicos demonstram tratar-se de uma doença infecto-contagiosa de alta morbidade e mortalidade, sendo o agente resistente à antibioticoterapia utilizada nos diferentes tratamentos empregados nas propriedades visitadas.

Os achados clínico-patológicos relatados neste estudo estão de acordo com as descrições de mormo feitas por Langenegger et al. (1960), Acha \& Szyfre (1986), Krishna et al. (1992), Jubb et al. (1993), Coetzer et al. (1994), Searcy (1995), Bazargani et al. (1996) e Al-Ani et al. (1998).

As propriedades bioquímicas das bactérias aqui isoladas de muares e eqüinos são semelhantes àquelas relatadas por Al-Ani et al. (1998). Os achados do bioquimismo bacteriano permitem classificá-las como Burkholderia mallei. Os achados microbiológicos e aqueles referentes à inoculação do inóculo bacteriano também estão plenamente de acordo com aqueles observados por Langenegger et al. (1960) e Muhammad et al. (1998).

Provavelmente, a principal forma de contágio ocorre através da ingestão de água e alimentos contaminados, com descarga nasal purulenta eliminada por animais doentes e infecção por inalação (Wilson \& Miles 1964). 0 tipo de manejo utilizado nas propriedades visitadas, com confi-namento dos animais em estábulos para alimentação, provavelmente está associado à disseminação do agente no ambiente, facilitando a infecção entre os animais.

A alimentação pobre, a movimentação de animais e o excesso de trabalho podem predispor à infecção; estes fatores foram observados nas propriedades visitadas.

Com relação à ocorrência da doença, observou-se não haver relação entre a estação do ano e o aumento do número de casos nas propriedades onde a doença assume caráter crônico, ocorrendo mortes durante todo 0 ano.

De fato, os efeitos da concentração de animais em estábulos coletivos têm grande impacto na epidemiologia do mormo em eqüídeos, sendo incriminado por Verma (1981) como 0 grande responsável pela disseminação da doença.

Os animais assintomáticos, na fase aguda da doença ou em estágios de convalescença, desempenham importante papel na transmissão direta e indireta do agente, pois apresentam a bactéria nas secreções cutâneas e respiratórias.

0 mormo era uma doença considerada erradicada no Brasil, o ressurgimento indica a necessidade de realização de inquéritos soro-epidemiológicos em todo o plantel de eqüídeos dos Estados de Pernambuco e Alagoas e naqueles suspeitos de ocorrência do mormo. Medidas de controle e profilaxia devem ser adotadas pelos órgãos competentes no sentido de evitar a disseminação do agente para regiões livres da doença.

\section{REFERÊNCIAS}

Acha P.N. \& Szyfre B. 1986. Zoonoses y Enfermidades Transmissíveis Comunes al Hombre y a los Animales. 2a ed. Publicación Científica no 503, Organizacion Panamericana de La Salud, p.131-135.

Al-Ani F.K., Al-Delaimi A.K. \& AliA. H. 1987. Glanders in horses: clinical and epidemiological studies in Iraq. Pakist. Vet. J. 7:126-129.

Al-Ani F.K., Al-Rawashdeh O.F., Ali A.H. \& Hassan F.K. 1998. Glanders in horses: clinical, biochemical and serological studies in Iraq. Veterinarski Arhiv 68(5):155-162.

Batteli C., Contente T., Corsalini G., Goffredo P., Lazari P., Puccini V. \& Sobrero L. 1973. Segnalazione di un episodio di morva rivelato in un gruppo di leoni in cattività. Vet. Ital. 24(87):112, 113, 116.

Bazargani T.T., Tadjbakhs H., Badii A. \& Zahraei T. 1996. The outbreak of glanders in some racehorses in three states of Iran. J. Equ. Vet. Sci. 16(6):232 $-236$.

Bishop G.C. 1994. Glanders, p. 1046-1050. In: Coetzer J.A.W., Thomson G.R. \& Tustin R.C. (ed.) Infectious Diseases of Livestock.. Vol. 1. Oxford University Press, Cape Town.

Dungworth D.L. 1993. The Respiratory System, p. 552-555. In: Jubb K.V.F., Kennedy P.C. \& Palmer N. (ed.) Pathology of Domestic Animals. Vol. 2. 4th ed. Academic Press, New York.

Gangulee R.C., Sen G.P. \& Sharma G.L. 1966. Serological diagnosis of glanders by haemagglutination test. Ind. Vet. J. 43(5):386-391.

Henning M.W. 1956. Animal Diseases in South Africa. 3rd ed. Central News Agency, Kelvin.

Krishna L., Gupta V.K. \& Masand M. R. 1992. Pathomorfological study of possible glanders in solipeds in Himachal Pradesch. Ind. Vet. J. 69:211-214.

Langenegger J., Döbereiner J. \& Lima A.C. 1960. Foco de mormo (Malleus) na região de Campos, estado do Rio de Janeiro. Arqs Inst. Biol. Animal, Rio de J., 3:91-108.

Muhammad G., Khan M.Z. \& Athar M. 1998. Clinico-microbiological and terapheutic aspects of glanders in equines. J. Eq. Sci. 9(3):93-96.

Pimentel W. 1938. História e organização do serviço veterinário do exército. Revta Milit. Med. Vet., Rio de J., 1(4):283-322.

Redfearn M.S., Allerani N.J. \& Stainer B.Y. 1966. A comparative study of Pseudomonas pseudomallei and Bacillus mallei. J. Gen. Microb. 43:293-313.

Searcy G. 1995. Hemopoietic system, p.305-352. In: Carlton W.W.R. \& McGavin M.D. Thomson's. Special Veterinary Pathology. 2nd ed. Mosby, St Louis.

Shumilov K.V. 1974. Comparative study of methods of diagnosis of glanders in horses in Mongolia. Trudy, Veses. Nogo. Inst. Eksperimentalnaia Vet. 42:272-282.

Verma R.D. 1990. A micro-complement fixation test for identification of Pseudomonas mallei. J. Remount. Vet. Corps. 29:1-5.

Verma R.D. 1981. Glanders in India with special reference to incidence and epidemiology. Ind. Vet. J. 58:177-183.

Verma R.D., Venkateswaran K. S., Sharma J. K. \& Agarwal G. S. 1994. Potency of partially purified malleo-proteins for mallein test in the diagnosis of glanders in equines. Vet. Microbiol. 41:391-397.

Yabuuchi E., Kosako Y. \& Oyaizu H. 1992. Proposal of Burkholderia genus and transfer of seven species of the genus Pseudomonas homology. J. Microbiol. Immunol. 36:1251-1275.

Wilson G.S. \& Miles A. 1964. Glanders and Melioidosis, p.1714-1717. In: Topley and Wilson's Principles of Bacteriology and Immunity. Edward Arnold, London.

Zhang W.D. \& Lu Z.B. 1983. Application of an indirect haemagglutination test for the diagnosis of glanders and melioidosis. Chin. J. Vet. Med. 9:8-9. 